\title{
Renewing the Moral Life: Some Recent Work in Virtue Theory
}

\section{Craig Paterson}

In responding to the Second Vatican Council's call for a renewal in moral theological reflection, Servais Pinckaers, Benedict Ashley, and Romanus Cessario, all Dominicans, are engaged in the earnest labour of authentically interpreting that call to renewal via a systematic examination of the sources of ethics contained in Sacred Scripture, Tradition, and natural reason.

The years since the Second Vatican Council have seen many divergent trends in moral method, not least the adoption of a widespread adherence to the methodology of proportionalism, particularly in the United States.' The above mentioned Dominicans reject such a method as being incompatible with those crucial sources of our faith. In contrast to the popularity of proportionalism, they are engaged in a quiet, patient, and determined project, centred on virtue theory, that is gradually bearing fruit.

In Sources of Christian Ethics, Pinckaers tackles the distorted picture of an ethic based solely on the demands of obligation. ${ }^{2}$ The search for the minimal content of obligation in Christian ethics has been corruptive of a fully integrated approach to ethical understanding, and its latent effects are manifested in the minimalism of proportionalism that reduces the moral life to a form of quasitechnical calculus based on the will of the acting subject. Quite simply, proportionalism as a method seems incapable of adequately accounting for our profound sense of personal integrity, and with it, the control we exercise over the constitution of our character expressed in virtuous and unvirtuous conduct.

Understanding of our acts operates on two layers. The first layer is the externally observable act. The second layer, lying near the centre of our being, goes much deeper. It stems from our capacity to reflect upon ourselves, our personal dispositions, intentions, and feelings. Here we are at the core of our being expressed in the biblical metaphor of the heart. This is where the virtues have their place, as personal dispositions to do good and avoid evil. 238 
When St Thomas Aquinas appeals to the profound effects of certain choices upon the character of the acting person, he is implicitly rejecting the ability of proportionalism to accommodate the organic unity in our actions that gives a person a profound sense that it is a life of authorship that they are living, a life that is integral to them and their character.

Proportionalism states that an action can be considered right or wrong depending on the nature of the state-of-affairs it would produce. ${ }^{3}$ We are not essentially concerned with the interior disposition of the agent when considering right and wrong acts. By weighing the various values and goods being sought, the agent focuses on the proportion acknowledged between the good and bad effects, with a view to the greater good or lesser evil actually possible in a particular situation. ${ }^{4}$ In this way, an act which seems to contradict an exceptionless moral norm, by directly violating "pre-moral" goods, could be qualified as morally acceptable, if calculation is focused on the pre-moral balance judged to be decisive.

Proportionalism tends to assume a theory of action that is practically indistinguishable from main stream consequentialism. Its features are aptly summed by John Finnis. It consists of a possible state-of-affairs to realize; a plan to bring about that state-of-affairs; and a series of performances to bring about the desired result. ${ }^{5}$ There is a clear central flaw running throughout the methodology of proportionalism. As a method it divorces us from the dynamic interiority of moral character. Judgement of actions is made at the pre-moral phase by an adjustment of circumstances and means to the end, in a kind of quasi-technical calculus. If we were to take proportionalism seriously as a practical method for the moral life it would seem to entail just such a destructive impact upon our constitutive sense of character by reducing character to a form of cost-benefit analysis.

Pinckaers, Ashley, and Cessario all realize the dangers proposed by such a method. In contrast, they all stress the unique and integrated aspects of a life well conducted in imitation of Christ and centred on the virtues. This is of course the project of St Thomas, a central source for renewal in the Tradition of the Church. Intrinsic evil, for example, is rendered sensible precisely because of the interior effects it has on the character of the acting person-an act's "first consequence". Certain choices and habits of action are fulfilling of us and embrace the good, in a way that only virtuous conduct can account for. Such a divorce from this interior aspect of the moral life will only result in an impoverished legalism that stresses the external 
conformity of behaviour without needing to address the deeper roots of morally good conduct. As Karol Wojtyla has stated, our freely chosen acts do not merely produce a change outside of oneself, but also are decisions about oneself, a life set for or against the good, the truth and ultimately for or against God. ${ }^{\circ}$

Pinckaers, returning to the basic sources, turns to St Paul as an exponent of an integrated, distinctively Christian calling. St Paul embraces the natural wisdom of human kind in the form of the virtues. However, the supernatural virtues of faith, hope, and love, call the Christian faithful to a higher level of human perfection. Grace transforms the hardness of human hearts and God is seen to be intimately involved in the redemption of human kind through the operation of the infused virtues.

It is this unique life in Christ that leads St Paul to reject a corrupting over-emphasis on legalism that leads all too readily to forms of laxism and a neglect of underlying goods. It also gives direction to the natural virtues that can degenerate and lead to the kinds of vice that the pagan civilizations of Greece and Rome were prone to.

Benedict Ashley, in his book, Living the Truth in Love, focuses on the supernatural virtues as the unique gift of God, standing in intimate relation to the natural virtues, perfecting them onto a higher plain of reality. ${ }^{7}$ Grace perfects what humanity had corrupted through that first sin of Eden. The relationship of the supernatural to the natural virtues is reflected in the organization of Ashley's text into a triadic structure centred on faith, hope, and love.

Ashley, as with Pinckaers, and Cessario, is committed to the notion that human nature, in the form of the virtues extolled by the Greeks, is an integral part of the moral wisdom of the New Testament. In his approach to the interpretation of Christian ethics he strives to be faithful to the synthesizing genius of St Thomas Aquinas.

In their historical analysis, Pinckaers and Ashley, are seeking to explain the undue emphasis on obligation that is said to have arisen from the voluntarist position of William of Ockham. Their work is an attempt to explain the trend that moved towards excessive attention to rules and duties that distanced them from the teleological nature of the goods that underpin all norms. There is a forceful delineation of this trend and an attempt to get back to the kind of synthetic approach St Thomas adopted between the virtues and the natural law written on human hearts.

Throughout, there is a common exhortation, that, if we are to 240 
proceed with a more adequate way of doing moral theology we need to get back to the kind of Thomistic approach that has been such a fruitful source of inquiry in the life of the Church."

Cessario's book, The Moral Virtues and Theological Ethics, similarly represents a contribution to the movement of rediscovering the role of the moral and theological virtues in the lives of the Christian faithful.' The use of virtue theory is seen as possessing greater explanatory powers in accounting for the uniquely distinctive aspects of leading a life modelled on Christ. We are called to a new life in Christ. This represents the unique infusion of God's grace into the heart of the converted, strengthened through the sacramental life of the Church. The New Testament is full of examples where this new life in Christ adds a transforming dimension to a life well lived through the way of Christ's passion on the Cross.

Pinckaers, Ashley, and Cessario are engaged in a dedicated attempt, along with others, to re-engage an ethics of virtue in order to explain the correspondences and departures between a secular life and a distinctively Christian life. This is represented in the model of Christ himself, who, as God made flesh, shows us how the divine end of our life transforms the realities of the natural world-grace perfects nature towards our final end.

The theological virtues of faith, hope, and love are not simply optional extras grafted on to the natural life. Rather, they stand as powerful vehicles for the transformation of the interior life of the faithful, and illuminate the natural virtues by showing the true end for humanity - union with God in eternal life.

Pinckaers, Ashley, and Cessario stress the unique and integrated aspects of a life lived well in Christ. Such a life demands much more from the individual than external conformity to the rules of the Ten Commandments. As St Paul reminds us, there is a fundamental need for conversion of the heart.

Our authors point out that, despite its attempt to offer some flexibility in how a moral life can be led, the school of thought known as proportionalism is really only another form of creeping legalism, to conform to or grant dispensations from rules, and with it a concomitant stress on conscience as a form of escape clause in an otherwise binding set of contracts. If we are to break free of this mind-set, the fullness of Christian living must be engaged in a life of virtue, which is a life of integrated human flourishing. Certain choices and habits of action are fulfilling of us and embrace the good in a way that only virtuous conduct can account for.

I was looking recently at a book on the paintings of the 
Renaissance, and it struck me most powerfully that what our Dominican Friars have in mind, is more truly represented by Michelangelo's frescoes on the ceiling of the Sistine Chapel than the medieval two-dimensional images of God as King and Lawmaker sitting upon the throne of judgement. The dimension of perspective adds shape and form to the depiction of God. This might stretch the metaphor to breaking point. However, the creative act of God imparting His Goodness and plenitude to the world, to Adam, is inherently more creative and dynamic that the image of God as some sort of sovereign feudal lord. Proportionalist authors may well be surprised to find that their moral method may actually more compatible with just such a two-dimensional image!

We are made in the image and likeness of God. We have the capacity to know the good and cultivate it in our hearts. Through our capacity for wisdom, we are able to discern the design of the Creator-the eternal telos-a plan for how we should conduct our lives. God's gift of faith to us helps us to overcome the clouds of forgetfulness that is the condition of original $\sin$.

How then can we fulfil the ends that God has given to us? Quite simply, it is to use the capacities that we possess to the correct ends that we are given in our natures, creatively and dynamically, as indeed God Himself is creative and dynamic. It is to the merit of our authors and their precursors (such as Josef Pieper) that we can understand more fully the call to virtuous living as a never-ending process towards excellence, authentic self-realization, and ultimately beatitude. ${ }^{10}$

As we have already recognized, all three of our authors draw heavily upon the teaching of St Thomas to unfold the forms of the virtues that incorporate this "synergy" of Christian living. We are given appetites-vegetative, animal, rational, and spiritual. Any account of the ethical life that does not recognize that there is a normative anthropology, is bound either to exalt bare rationality, as Kant did, or, exalt desire alone, as the Romantics did. However, we are a unity of the different dimensions of the life we are given. The form of the virtues seems to account for this unitative aspect of our nature in a way that avoids contrary forms of reductionism.

Prudence, justice, fortitude, and temperance, are the cardinal natural virtues that guide us on the path of life. These virtues do not stand alone but rather dynamically relate to the supernatural virtues. In the life of the faithful, these supernatural virtues carry the cardinal virtues to greater heights. Thus, temperance, for example, is given added dimensionality in the life of the faithful via abstinence during 
Lent. Natural prudence is augmented and elevated by grace via the guidance of the Holy Spirit. Courage, to resist temptation under fire, in the face of persecution, is heightened. Witness here the lives of the blessed martyrs who resist the denial of faith when natural virtue seems to lose its capacity to hold steadfastly to the truth that is God. Faith, hope, and love help us to overcome the fissures of confusion where our unassisted nature alone seems to fail.

When reflecting upon the nature of the virtues, it seems fitting that we should look to the lives of the saints that God has called to the ranks of the blessed. St Thomas More, for example, was able, through God's grace, to hold with fortitude to the witness of the Church and not deny the sacramental realities of the faith in marriage, or the fidelity owed to Peter's successors. "This brings into unique relief the role of the Church in guiding us to our end of union with God.

Pinckaers, Ashley, and Cessario all stress that a life of virtue enables us to understand how we can live up to the great challenges of life that confront us all. Virtues impregnate the moral life with a dynamic meaning in a way that moral life is not "forced" but creative and rewarding-rewarding because authentic flourishing enables us to see the unity in a life well lived: God's call to us and our response.

Given the full dimension of our nature, a life of virtue enables us to act imaginatively in response to our ends: ends that God has given us because they are good as $\mathrm{He}$ is good. A life that integrates the virtues under the guidance of prudence enables us to grasp its profoundly creative dimensions of friendship, love, trust, and fidelity. The fullness of marriage, for example, cannot simply be understood as an imposition of laws and rules. To be fulfilled, impregnated with authentic meaning, in a manner somewhat analogous to the pouring forth of God's creativity, it calls us to embrace justice in domestic relationships, temperance when passion sometimes seems to overwhelm our measure of appropriateness, fortitude and mutual support in the face of failing health.

Habitus is the cultivation of appropriate interior states of relationality to the call of the good manifested in the ends of our created lives. It is a shaping of our life in co-operation with God's plan. Peter Kreeft has summed up well the operation of habitus in his book Back to Virtue. There was a man in Times Square, New York, who had a violin case under his arm. The young man asked a nearby policeman "How can I get to Carnegie Hall?" The policeman answered "Practice, man, practice."!'2

A life well led must integrate the narrative of episode into a weaved framework of meaning and context ordained to the summum 
bonum. Prudence is the guiding light that seeks to direct us into a coherent whole that is real because it is creatively ordered to ends that fulfil us. Prudence, therefore, enables us to form the harmonious correspondence in our own lives that orders us to understand our authentic purposes and realize them within ourselves. Ultimately, it is only with God's help via the infusion of the supernatural virtues that we can fully realize the harmony necessary to grasp this interior goodness, not with the iron rod of external threat, but with a tender openness of heart to God's call.

As Benedict Ashley writes: "Christian moral wisdom is to be found not merely in particular good acts, but in the character of a person who has the constant capacity to live as a Christian day in and day out in all kinds of circumstances. As Jesus says in the Sermon on the Mount, 'A good tree cannot bear bad fruit, nor can a rotten tree bear good fruit" (Mt 7:18)."13

1 See generally Bernard Hoose, Proportionalism: The American Debate and its European Roots (Washington, DC: Georgetown University Press, 1987).

2 Servais Pinckaers, O.P., The Sources of Christian Ethics. 3rd ed. Mary Noble trans (Washington D.C.: Catholic University of America Press, 1995).

3 Garth Hallett, S.J., The Greater Good: The Case for Proportionalism (Washington, DC: Georgetown University Press, 1995), 2.

4 Hallett, Greater Good, 10.

5 John Finnis, "The Act of the Person," in Persona Verita, e Morale: Atti del Congresso Internazionale di Teologia Morale (Rome: Citta Nuova Editrice, 1987), 159-75, 165.

6 Karol Wojtyla, The Acting Person. Andrzej Potocki trans. (Dordrecht; Boston: D. Reidel, 1979), 11, 160.

7 Benedict N. Ashley, O.P., Living the Truth in Love: A Biblical Introduction to Moral Theology (New York: Alba House, 1996).

8 Just such a source of renewal can be seen in Fides et Ratio, the recent papal encyclical on the relationship between faith and reason.

9 Romanus Cessario, O.P., The Moral Virtues and Theological Ethics (South Bend, IN: University of Notre Dame Press, 1990).

10 Josef Pieper, The Four Cardinal Virtues: Prudence, Justice, Fortitude, Temperance (South Bend, IN: University of Notre Dame Press, 1966)

11 For an excellent new biography of St Thomas More see Peter Ackroyd, The Life of Thomas More (London: Chatto \& Windus, 1998).

12 Peter Kreeft, Back to Virfue: Traditional Moral Wisdom for Modern Moral Confusion (San Francisco: Ignatius Press, 1992), 67.

13 Ashley, Living the Truth, 111. 